\title{
Significant Enhancements in a New Edition Make a Cell Biology Text Well Worth Considering
}

\author{
Review of: Cell Biology, 3rd Edition, by Thomas D. Pollard, William C. Earnshaw, \\ Jennifer Lippincott-Schwartz, and Graham Johnson; 2017; 908 pp.; Elsevier \\ (New York); ISBN: 9780323341264 (print and eBook editions)
}

Reviewed by David Burgess*, Biology Department, Boston College, Chestnut Hill, MA 02467

A s I teach cell biology to mostly sophomores and junior undergraduates, the opportunity presents itself every few years to adopt a new edition of a cell biology textbook. Historically, I have used Alberts and colleagues' Essential Cell Biology, now in its fifth edition. A few years ago, I tried the second edition of Pollard and Earnshaw's Cell Biology in my undergraduate cell biology course. As a practicing cell biologist, I appreciated the research-based presentation of Pollard and Earnshaw's text, but my students did not respond well to the density of the writing, which seemed over their heads.

When I was asked by the authors to review and comment on a draft chapter of the third edition of Pollard's text, I was immediately struck by the new style of presentation. This edition brings new coauthors, Jennifer Lippincott-Schwartz and Graham Johnson, and a refreshed writing style that seems more readable for undergraduates. There has also been significant updating of the content, making the text current with research in the field of cell biology.

Authors Pollard, Lippincott-Schwartz, and Earnshaw are longtime leaders in research in different areas of cell biology, and Johnson is an outstanding modern illustrator of cells. They convey the excitement of research and bring a critical eye to the current state of cell biological understanding in each chapter. The textbook is organized into 10 sections from the chemistry of macromolecules to the cell cycle and provides comprehensive coverage of the topics. A few chapters benefited from contributions by other experts. For example, the chapter on gene expression is written by Jeffry Corden, the chapter on eukaryotic RNA processing was authored by David Tollervey, and the chapter on protein synthesis and folding was revised from initial edition version authored by William Balch, Ann Hubbard, J. David Castle, and Pat Shipman.

Even though the chapters are authored by different scientists, they flow nicely and draw appropriately from current research, findings, and tools from different subdisciplines. For example, there are crystal structures of proteins derived from work by biophysicists, rate and dissociation constants done by biochemists, and measurements of membrane potential by neuroscientists, each illustrating the interdisciplinary and quantitative nature of cell biology. Each chapter discusses disease in terms of mutations interfering with the functions of specific proteins in pathways or cellular assemblies, highlighting both the societal relevance and systems nature of cell biology. The chapter on methods and research strategies, including the affordances of different model systems, makes clear how cell biological research is done and introduces the role of mathematical modeling. The authors use molecular structures as a way of examining how systems work, which in my experience is novel among texts. For instance, in the chapter on the cytoskeleton and cellular motility, the molecular structure of the Arp2.3 complex leads to an accurate model of a branching point on an actin filament that expands further to an illustration of the regulation of the branching pathway. This figure elegantly illustrates and simplifies a complex cellular machine.

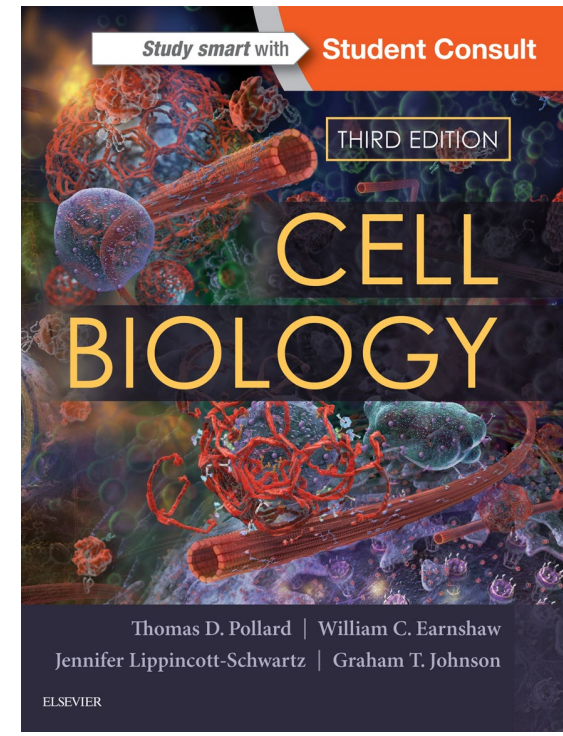

CBE Life Sci Educ June 1, 2019 18:fe2 DOI:10.1187/cbe.19-03-0057

*Address correspondence to: David Burgess (david burgess(abc.edu).

(C) 2019 D. Burgess. CBE-Life Sciences Education (C) 2019 The American Society for Cell Biology. This article is distributed by The American Society for Cell Biology under license from the author(s). It is available to the public under an Attribution-Noncommercial-Share Alike 3.0 Unported Creative Commons License (http:// creativecommons.org/licenses/by-nc-sa/3.0). "ASCB®" and "The American Society for Cell Biology ${ }^{\circledR}$ " are registered trademarks of The American Society for Cell Biology. 
The huge number of molecular structures included in all chapters, along with the illustrations of proteins and structures drawn accurately to scale, will likely make the approach more accessible to students and hopefully lead to a better understanding of the material. In fact, Johnson's illustrations are a true strength of the textbook, as they accurately depict structures in three dimensions and tie the text together.

Thus, in general, the text has been edited to align with the core competencies of Vision and Change in Undergraduate Biology Education (American Association for the Advancement of Science, 2011), specifically the ability to

- apply the process of science;

- use quantitative reasoning;

- use modeling and simulation;

- tap into the interdisciplinary nature of science;

- communicate and collaborate with other disciplines; and

- understand the relationship between science and society.

Many chapters could have been strengthened further by inclusion of a discussion of where the field is going, highlighting open questions requiring a next generation of researchers, rather than implying that everything is known.

Another strength of the text is that approximately $80 \%$ of the coverage is of material outside the nucleus. Undergraduates in my course have been inundated with information about macromolecules, chromatin, genes, and transcription. Having the bulk of a cell biology text presenting information about the experimental basis of how cells work posttranscription is not only novel for them but also important for understanding cell biology more generally. The authors have had experts in each of the content areas review and suggest edits for each chapter, and their work has ensured that the material is current and accurate. Some of the chapters are much more detailed than others, but this allows instructors to select parts of these chapters to cover in class and direct students to other parts as reference material. Each subject is accompanied by information on its health relevancy, which will likely help to engage those students intending to pursue health careers. Although cancer is referenced in many chapters, I would have liked to see a separate chapter on cancer, which is of interest to my students.

This book has one glaring weakness: the online supporting materials. There are very few animations, a total lack of movies of cells in action, and a very limited exam bank. This weakness is surprising, because Johnson is director, Animated Cell at the Allen Institute, and the other authors use live-cell imaging of fluorescent proteins in their research. Cell biology today has the potential to captivate students and give them a more realistic sense of the dynamicity of cells because of the many movies of proteins and organelles in action in living cells. Although many movies can be found on YouTube, having a curated set to accompany the text would have been helpful in assembling new lectures when adopting the new textbook (although all figures are available as PowerPoint slides in the online materials). The limited number of animations in the student eBook is a teaser of what could have been done. The exam bank for instructors does not appear to be much updated from the previous editions. The questions provided are all multiple choice, and many require students to synthesize information and not just memorize facts. Although I tend to create my own short-answer questions, I would have appreciated exam questions with more varied formats.

All in all, I recommend this cell biology textbook, as in my view, the strengths definitely outweigh the weaknesses. I look forward to seeing how my next group of cell biology students responds.

\section{REFERENCE}

American Association for the Advancement of Science. (2011). Vision and change in undergraduate biology education: A call to action. Washington, DC: National Academies Press. 